\title{
Influence of the North Atlantic Oscillation on Mediterranean deep-sea shrimp landings
}

\author{
Francesc Maynou* \\ Institut de Ciències del Mar (CSIC), Psg. Marítim de la Barceloneta 37-49, 08003 Barcelona, Spain
}

\begin{abstract}
Recent studies have shown that the population dynamics of deep-sea organisms are affected by coupling between surface oceanic processes and energy, or trophic resources, reaching the sea floor. I analysed the correlation between the landings of a deep-sea shrimp (Aristeus antennatus) in Catalonia (NW Mediterranean) and the climatic indices of the annual North Atlantic Oscillation (NAO) and winter NAO between 1971 and 2007. I show that the size of landings is significantly correlated with the NAO and with the winter NAO, with 2 and 3 yr lags in both cases. Considering that around $60 \%$ of the landings comprise 2 to 3 yr old females, my results suggest that climatic conditions over the western Mediterranean (especially in winter) influence the year-class strength of this deep-sea shrimp, fished from 600 to $800 \mathrm{~m}$ depth.
\end{abstract}

KEY WORDS: Aristeus antennatus $\cdot \mathrm{NAO} \cdot$ Deep-sea $\cdot$ Benthic-pelagic coupling Resale or republication not permitted without written consent of the publisher

\section{INTRODUCTION}

The North Atlantic Oscillation (NAO) is the most prominent atmospheric phenomenon over the middle and high latitudes of the Northern Hemisphere (Hurrell et al. 2003, Stenseth \& Mysterud 2005). The NAO has profound implications on the weather over the North Atlantic and Europe, but also on terrestrial and marine environments, affecting human economic activities, such as agricultural harvests and fisheries yields (Stenseth et al. 2002, Drinkwater et al. 2003, Hallett et al. 2004). The main influence of the NAO on European weather consists in increased precipitation in Atlantic Europe and decreased precipitation in Mediterranean Europe during high-NAO winters and the opposite precipitation pattern during low-NAO winters. This variation in rainfall, together with associated changes in air temperature, winds and river runoff, determine the characteristics of Mediterranean water masses (Hurrell 1995, Mariotti et al. 2002). The existence of clear patterns linking the NAO with surface marine ecological processes has been demonstrated in several studies, especially in shallow waters (Stenseth et al. 2002, Drinkwater et al. 2003). The vari- ations in environmental parameters linked to the NAO may act on biological organisms at different levels (individual, population) through physiology (metabolic and reproductive processes) or through trophic relationships, including ecological cascade effects (Stenseth et al. 2002, 2003). The NAO is an excellent proxy for long-term series on environmental variables, which are often not available, especially in the deep sea, and it often has a higher predictive power for ecological processes than for local environmental variables (Hallett et al. 2004, Stenseth \& Mysterud 2005).

The red shrimp Aristeus antennatus is an important target species of the trawl deep-water fishery in the western Mediterranean. Along the Catalonian coast (300 km length, NW Mediterranean) it is fished yearround by ca. 100 medium-sized trawling vessels on bathyal fishing grounds from 600 to $800 \mathrm{~m}$ depth. The landings are composed mainly of adult females (ca. 90\% according to Maynou et al. 2006) and show important interannual fluctuations. Because this is a highly specialised deep-sea fishery, where red shrimp is the target species, I assume that the landings (i.e. what is brought to shore) are a valid index of abundance of the population. Given the logistic difficulties 
and high cost of obtaining long data series of deepwater population abundance (Billett et al. 2001), I used the time series of landings for $A$. antennatus to investigate the role of environmental variability (using the NAO index as a proxy) in explaining the fluctuations of a key component of the Mediterranean deep-sea fauna.

\section{MATERIALS AND METHODS}

Landings of the red shrimp Aristeus antennatus for the study area (Catalonia) were obtained from Martín (1991) for the period from 1971 to 1987 and from the Fisheries Directorate of the Catalonian Autonomous Government for 1988 to 2007 (unpubl. data). Data on total trawl engine power are available from the same sources for the 2 periods indicated, although not specifically for the trawl fishery analysed here. Because the red shrimp trawl fishery is a highly specialised deepsea fishery, where the shrimp is the target species due to its high price, I assume that landings are a valid index of abundance of the population. The evolution of landings and total trawl engine power (HP) for the period from 1971 to 2007 are shown in Fig. 1. This figure shows that the increase in landings after the early 1980s can be explained in part by increasing fishing capacity, and, for this reason, the landings series was detrended (Fig. 2a). Detrending the original landing series consisted of fitting a linear regression to the landings data, with time as the independent variable (Abraham \& Ledolter 1983, p. 95-100). This approach has the advantage of rendering the landings series stationary (as seen by the rapid decay of the sample autocorrelation function; not shown), without completely removing autocorrelation (see Pyper \& Peterman 1998, p. 2128 for the drawbacks of 'pre-whitening' and first-differencing of ecological data).

The annual averaged and the winter NAO indices were obtained from the Climatic Research Unit of the University of East Anglia (Norwich, UK), with updates provided by Tim Osborn (www.cru.uea.ac.uk/ timo/ projpages/nao_update.htm).

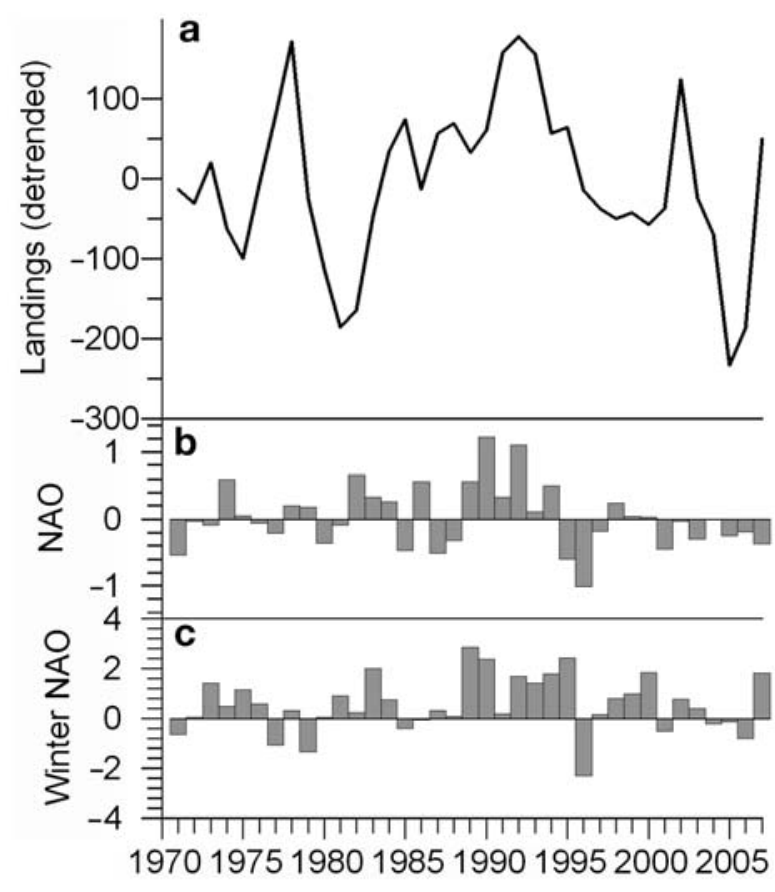

Fig. 2. (a) Detrended time-series of landings of red shrimp Aristeus antennatus, (b) annual NAO index and (c) winter NAO index

The time series analysis of red shrimp landings and the 2 NAO indices was performed with Box and Jenkins methodology (Abraham \& Ledolter 1983), using the $\mathrm{R}$ statistical package (R Development Core Team 2006). The time series analysis consisted of calculating the cross-correlation functions between the NAO and winter NAO as explanatory variables and the detrended shrimp landings series as a dependent variable. The cross-correlation functions lagged from 0 to $5 \mathrm{yr}$ (maximum age observed in the population analysed; Maynou et al. 2006). The values of cross-correlation were tested for significance using the modified Chelton method, as given in Pyper \& Peterman (1998) to correct the p-values for serial autocorrelation.

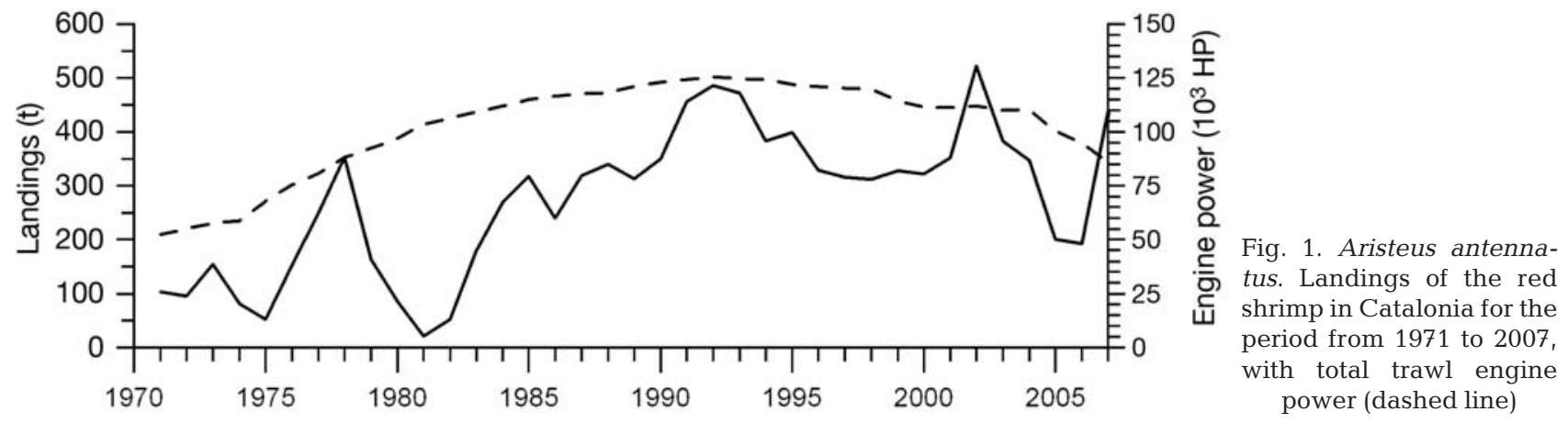




\section{RESULTS}

Both landings and the detrended time series of landings (Figs. 1 \& 2a) show clear interannual fluctuations, at approximately decadal scales. Years of peak abundance (e.g. 1978, early 1990s, 2002) coincide with a sequence of positive, or weakly negative, NAO years (Fig. 2b). More clearly, years of peak abundance follow a sequence of positive winter NAO years (Fig. 2c). The cross-correlograms between NAO (and winter NAO) and Aristeus antennatus landings shows that detrended landings are significantly correlated with the same indices of 2 and 3 yr before (Fig. 3a,b).

\section{DISCUSSION}

Studies showing direct or indirect links between surface primary production and deep-sea megabenthic population dynamics are available for short time scales (e.g. seasonal variations: Billett et al. 1983, Cartes 1994, Maynou et al. 1996). Studies linking surface processes with bathyal or abyssal ecology over longer time periods are scarcer, due to the logistics of obtaining longterm population data for deep-sea ecosystems (Billett et al. 2001, Danovaro et al. 2001, Bailey et al. 2006).

Using the NAO index as a proxy for environmental local processes (Hallett et al. 2004) in the atmosphere and surface waters and assuming that landings reflect the temporal dynamics of the population, my results show that these environmental processes have an impact on the temporal dynamics of deep-sea living resources (at least down to $800 \mathrm{~m}$ depth, the lower limit of the red shrimp Aristeus antennatus fishery), providing evidence for strong bentho-pelagic coupling in the NW Mediterranean. Tunberg \& Nelson (1998) also found that the NAO signal was positively correlated with abundance and biomass of soft-bottom macrofauna in deep waters of the Skagerrak and proposed

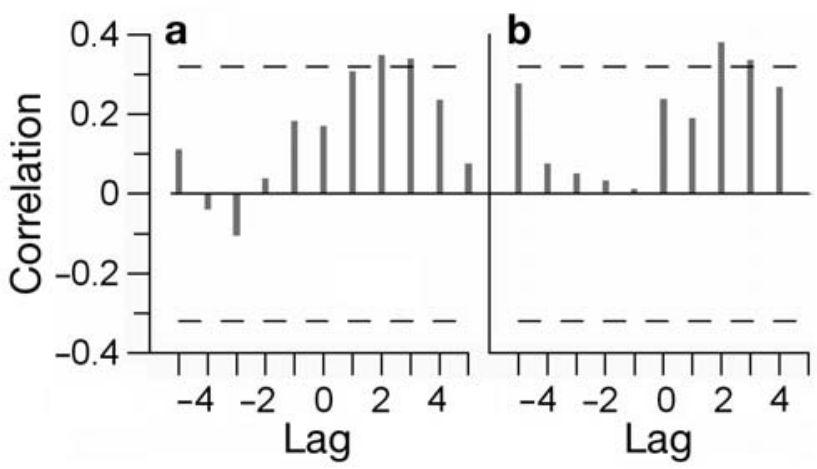

Fig. 3. Aristeus antennatus. Cross-correlations (a) between the annual NAO index and detrended landings of red shrimp and (b) between the winter NAO index and detrended landings. Dashed lines: $95 \%$ confidence intervals that this correlation was due to bottom-up control of benthic populations through influence of the NAO on primary production. Billett et al. (2001) suggested that long-term changes of the abundance of phytodetritus reaching the sea floor at $4840 \mathrm{~m}$ depth on the Porcupine Abyssal Plain (NE Atlantic) directly determined the abundance of holothurians feeding on phytodetritus. Danovaro et al. (2001) have also shown relatively rapid responses of deep-sea bacterial and meiofaunal communities to surface-water variations over decadal time scales in the eastern Mediterranean.

My results suggest that the annual strength of red shrimp landings is determined by variations in climatic conditions (especially in winter) in the previous 2 or 3 yr. Considering that 2 and 3 yr old females constitute $>60 \%$ of red shrimp landings in Catalonia (Maynou et al. 2006), it is the variations in the abundance of these age classes that are most likely reflected in the fluctuation of red shrimp landings.

It is known that recruitment in fish populations is a key process determining year-class strength and is strongly influenced by environmental variability (Chambers \& Trippel 1997), but very little is known about the population dynamics of red shrimp early life stages. Sardà \& Cartes (1997) showed that the smallest individuals of red shrimp appear on bottoms deeper than $1000 \mathrm{~m}$, but the scarce data available preclude any quantitative analysis. Thus, it is reasonable to seek an explanation for the relationship between the NAO and shrimp landings based on what is known about the life cycle of juveniles and adults of this species. The information provided by Cartes $(1994,1998)$ on red shrimp diet and trophic dynamics helps conceive a plausible hypothesis to explain my results: the relationship between NAO and fish abundance has been shown to be mediated through zooplankton production in many studies (Drinkwater et al. 2003), and Cartes $(1994,1998)$ showed that maturing adult females of Aristeus antennatus switch their opportunistic diet of endobenthic prey to suprabenthos and meso-zooplankton, of higher energy content, during late winter and spring. Increased food availability to maturing females during this critical period would enhance reproductive output (Fanelli \& Cartes 2008).

The teleconnection NAO-Mediterranean was shown by Hurrell (1995) and is expected to be a determinant of Mediterranean winter weather. Mariotti et al. (2002) reported that positive NAO winters induced higher sea-level pressure over the Azores and the western Mediterranean, resulting in relatively drier winters. Years with positive winter NAO thus result in winter water deficit in the Mediterranean basin (decreased precipitation) and lower river run-off of the major rivers in the NW Mediterranean (the Rhone and the Ebro Rivers). These changes in evaporation and fresh- 
water flux will produce significant variations in the characteristics of Mediterranean waters, resulting in relatively saltier, and denser, upper layers in coastal waters. This oceanographic situation leads to increased vertical mixing of the water masses in the NW Mediterranean, especially in the Gulf of Lions, through cascading of dense shelf waters (Font et al. 2007) and exchange of particulate matter (Durrieu de Madron et al. 1999, Heussner et al. 2006), which enhances local secondary production and ultimately increases mesozooplankton and other trophic resources to deep-water food webs (Molinero et al. 2008).

I propose that decreased rainfall during positive NAO years (especially with positive winter NAO) may increase water-mass mixing in the NW Mediterranean, enhancing meso-zooplankton production and food resources to Aristeus antennatus, especially in late winter when females are undergoing ovary maturation and require higher energy input. During years of enhanced food resources the reproductive potential of females would increase, and strengthen particular year classes that appear in the landings 2 to 3 yr later. Research to confirm this hypothesis should aim at quantitatively determining the role of the NAO on the dynamics of meso- and bathypelagic trophic webs, especially at lower trophic levels, in the NW Mediterranean. Additionally, if the hypothesis proposed here is confirmed, a strategy for conserving this important fishery should concentrate on protecting the spawning stock, either by reducing fishing effort on mature females in late winter and spring, or protecting spawning grounds, because spawning females are spatially segregated from males (Sardà et al. 1997).

My results may add to the limited number of studies showing that large-scale atmospheric phenomena may determine deep-sea population dynamics (Lehodey \& Grandperrin 1996, Tunberg \& Nelson 1998, Danovaro et al. 2001, Ruhl \& Smith 2004) and, in the deep NW Mediterranean, fisheries production.

Acknowledgements. I thank Mr. M. Sans, General Director of the Fisheries Directorate of the Catalonian Autonomous Government, for access to their fisheries landings database.

\section{LITERATURE CITED}

Abraham B, Ledolter J (1983) Statistical methods for forecasting. Wiley series in probability and statistics. John Wiley and Sons, New York

Bailey DM, Ruhl HA, Smith KL Jr (2006) Long-term change in benthopelagic fish abundance in the abyssal northeast Pacific Ocean. Ecology 87:549-555

Billett DSM, Lampitt RS, Rice AL, Mantoura RFC (1983) Seasonal sedimentation of phytoplankton to the deep-sea benthos. Nature 302:520-522

Billett DSM, Bett BJ, Rice AL, Thurston MH, Galéron J, Sibuet
M, Wolff GA (2001) Long-term change in the megabenthos of the Porcupine Abyssal Plain (NE Atlantic). Prog Oceanogr 50:325-348

Cartes JE (1994) Influence of depth and season on the diet of the deep-water aristeid Aristeus antennatus along the continental slope (400 to $2300 \mathrm{~m}$ ) in the Catalan Sea (western Mediterranean). Mar Biol 120:639-648

Cartes JE (1998) Feeding strategies and partition of food resources in deep-water decapod crustaceans (400-2300 m). J Mar Biol Assoc UK 78:509-524

Chambers CR, Trippel A (1997) Early life history and recruitment in fish populations. Chapman \& Hall, New York

Danovaro R, Dell'Anno A, Fabiano M, Pusceddu A, Tselepides A (2001) Deep-sea ecosystem response to climate changes: the eastern Mediterranean case study. Trends Ecol Evol 16:505-510

Drinkwater KF, Belgrano A, Borja A, Conversi A and others (2003) The response of marine ecosystems to climate variability associated with the North Atlantic Oscillation. In: Hurrell JW, Kushnir Y, Ottersen G, Visbeck M (eds) The North Atlantic Oscillation: climatic significance and environmental impact. Geophysical Monograph 134, American Geophysical Union, Washington, DC, p 211-234

Durrieu de Madron X, Radakovitch O, Heussner S, Loye-Pilot MD, Monaco A (1999) Role of the climatological and current variability on shelf-slope exchanges of particulate matter. Evidence from the Rhône continental margin (NW Mediterranean). Deep-Sea Res 46(Part I):1513-1538

Fanelli E, Cartes JE (2008) Spatio-temporal changes in gut contents and stable isotopes in two deep Mediterranean pandalids: influence on the reproductive cycle. Mar Ecol Prog Ser 355:219-233

Font J, Puig P, Salat J, Palanques A, Emelianov M (2007) Sequence of hydrographic changes in NW Mediterranean deep water due to the exceptional winter of 2005. Sci Mar 71:339-346

Hallett TB, Coulson T, Pilkington JG, Clutton-Brock TH, Pemberton JM, Grenfell BT (2004) Why large-scale climate indices seem to predict ecological processes better than local weather. Nature 430:71-75

> Heussner S, Durrieu de Madron X, Calafat A, Canals M, Carbonne J, Delsaut N, Saragoni G (2006) Spatial and temporal variability of downward particle fluxes on a continental slope: lessons from an 8-yr experiment in the Gulf of Lions (NW Mediterranean). Mar Geol 234:63-92

> Hurrell JW (1995) Decadal trends in the North Atlantic Oscillation: regional temperatures and precipitation. Science 269:676-679

Hurrell JW, Kushnir Y, Ottersen G, Visbeck M (2003) An overview of the North Atlantic Oscillation. In: Hurrell JW, Kushnir Y, Ottersen G, Visbeck M (eds) The North Atlantic Oscillation. Climatic significance and environmental impact. Geophysical Monograph 134, American Geophysical Union, Washington, DC

> Lehodey P, Grandperrin R (1996) Influence of temperature and ENSO events on the growth of the deep demersal fish alfonsino, Beryx splendens, off New Caledonia in the western tropical South Pacific Ocean. Deep-Sea Res II 43:49-57

Mariotti A, Struglia MV, Zeng N, Lau KM (2002) The hydrological cycle in the Mediterranean region and implications for the water budget of the Mediterranean Sea. J Clim 15:1674-1690

Martín P (1991) La pesca en Cataluña y Valencia (NO Mediterráneo): análisis de series históricas de captura y esfuerzo. Inf Tec Sci Mar 162:1-43

Maynou F, Conan G, Cartes JE, Company JB, Sardà F (1996) 
Spatial structure and seasonality of crustacean decapod populations on the northwestern Mediterranean slope. Limnol Oceanogr 41:113-125

Maynou F, Sardà F, Tudela S, Demestre M (2006) Management strategies for red shrimp (Aristeus antennatus) fisheries in the Catalan Sea (NW Mediterranean) based on bioeconomic simulation analysis. Aquat Living Res 19: 161-171

Molinero JC, Ibanez F, Souissi S, Buecher E, Dallot S, Nival $P$ (2008) Climate control on the long-term anomalous changes of zooplankton communities in the northwestern Mediterranean. Glob Change Biol 14:11-26

Pyper BJ, Peterman RM (1998) Comparison of methods to account for autocorrelation in correlation analysis of fish data. Can J Fish Aquat Sci 55:2127-2140

R Development Core Team (2006) R: a language and environment for statistical computing. R Foundation for Statistical Computing, Vienna. Available at www.R-project.org

Ruhl HA, Smith KL Jr (2004) Shifts in deep-sea community structure linked to climate and food supply. Science 305:513-515

Sardà F, Cartes JE (1997) Morphological features and eco-

Editorial responsibility: Nils Chr. Stenseth,

Oslo, Norway logical aspects of early juvenile specimens of the aristeid shrimp Aristeus antennatus (Risso, 1816). Mar Freshw Res 48:73-77

Sardà F, Maynou F, Talló L (1997) Seasonal and spatial mobility patterns of rose shrimp Aristeus antennatus in the western Mediterranean: results of a long-term study. Mar Ecol Prog Ser 159:133-141

Stenseth NC, Mysterud A (2005) Weather packages: finding the right scale and composition of climate in ecology. J Anim Ecol 74:1195-1198

Stenseth NC, Mysterud A, Ottersen G, Hurrell JW, Chan KS, Lima M (2002) Ecological effects of climate fluctuations. Science 297:1292-1296

Stenseth NC, Ottersen G, Hurrell JW, Mysterud A and others (2003) Studying climate effects on ecology through the use of climate indices: the North Atlantic Oscillation, El Niño Southern Oscillation and beyond. Proc R Soc Lond B Biol Sci 270:2087-2096

Tunberg DG, Nelson WG (1998) Do climatic oscillations influence cyclical patterns of soft bottom macrobenthic communities on the Swedish west coast? Mar Ecol Prog Ser 170:85-94

Submitted: December 7, 2007; Accepted: April 7, 2008 Proofs received from author(s): May 29, 2008 